\title{
A Bossa Nova e a música cearense dos anos 70
}

\author{
Nelson Barros da Costa (Universidade Federal do Ceará) \\ nelson@ufc.br
}

\author{
Maria das Dores Nogueira Mendes (Universidade Federal do Ceará / CNPq) \\ dasdoresnm@yahoo.com.br
}

\begin{abstract}
Resumo: Neste artigo procuramos mostrar que a atitude antibossanovista evidenciada no plano da expressão musical nas vozes, nos gêneros e nos arranjos das canções do "Pessoal do Ceará" também se manifesta no plano textual das canções desses artistas que apareceram na década de 1970 no cenário musical brasileiro. A fim de ilustrar essa discussão, analisamos as canções Berro e Abertura (EDNARD0, 1976) sob o ponto de vista da Análise do Discurso. As conclusões ratificam a tese de que, paralela à linha evolutiva aberta pela Bossa Nova no discurso literomusical brasileiro, outras linhas, que se originaram em ambiente musical mais distanciado do sudeste do país, evoluíram a um só tempo explorando o veio aberto pela estética bossanovista e se demarcando desta tanto nos textos como na expressão musical.
\end{abstract}

Palavras-chave: Bossa Nova, música cearense, polêmica discursiva.

\section{The Bossa Nova movement and the music of Ceará of the 1970s}

Abstract: In this paper we show that the antibossanovist attitude evidenced musically by the voices, the genres and arrangements of the artists of "Pessoal do Ceará" also occurs in the textual aspect of the songs of these artists who appeared in the Brazilian music scene in the 1970s. To illustrate this discussion, we analyze the songs Berro and Abertura (EDNARD0, 1976) from the point of view of discourse analysis. The findings reinforce the thesis that in parallel to the evolutionary line opened by Bossa Nova movement in the popular Brazilian music, other lines, originating from musical environments far from southeastern Brazil, evolved at the same time exploring opportunities offered by Bossa Nova and drawing an own musical and textual style.

Keywords: Bossa Nova movement, music of Ceará, discursive polemic.

\section{1 - 0 projeto Bossa Nova}

Se é possível situar um ponto no tempo em que a Bossa Nova surgiu, este ponto é o início do ano de 1959, quando foi lançado o LP Chega de saudade, de João Gilberto, onde estão os sucessos Desafinado, Lobo bobo, além da incrivel canção que dá título ao disco. Um ano antes já havia sido lançado o LP Canção do amor demais, de Elizeth Cardoso, mas, apesar de ter a participação de dois fundadores do movimento, Antônio Carlos Jobim e João Gilberto, não é um disco de Bossa Nova, pois Elizeth canta as canções de Tom e Vinicius com uma dicção tradicional, bastante distante da dicção que notabilizou o movimento.

0 impacto foi o do deslumbre da invenção que vai ao encontro da ânsia pelo novo resultante da insatisfação dos jovens e do cansaço dos já não tão jovens diante do cenário musical da época. Que cenário era esse? De um lado, os sambões e as marchinhas de carnaval, herdeiros da tradição, muitos deles eufóricos e ufanistas ao extremo; de outro, os sambas-canção e os bolerões, marca da penetração da música latina no Brasil, melancólicos e saturados de tristeza. De outro lado, ainda, as valsas e serestas, herdeiras da tradição lírica portuguesa, nostálgicas e românticas em demasia. Podese apontar ainda a presença das canções de extração rural, seja do Nordeste, seja da realidade interiorana dos diversos estados do sul e do sudeste do país. Sentia-se nessas canções igualmente o excesso do telúrico e do nostálgico, sentimentos já atropelados pelo acelerado processo de urbanização da época.

Diante de tal realidade, faz parte das condições de produção da Bossa Nova o desgaste e esgotamento desses excessos, e, ao mesmo tempo, um projeto que aponta para uma ruptura concreta com esse estado de coisas sem descurar do senso estético sobre o qual se fundara a canção brasileira. Esse perfeito encaixe entre necessidade de superação e perspectiva de materialização de um projeto alternativo explica o grande impacto que causou a Bossa Nova. Para se ter uma ideia dessa comoção, 0 pesquisador Zuza Homem de Mello (MELLO, 2001), em 
seu livro sobre João Gilberto publicado pela Publifolha, relata que muitos artistas compararam o choque que tiveram ao ouvir pela primeira vez o cantor baiano com o que tiveram diante de acontecimentos como a chegada do homem à Lua ou a morte do Presidente Kennedy.

No fundo, a novidade da Bossa Nova é atingir, de modo eficaz, a contenção dos excessos referida anteriormente sem se retirar do projeto estético estabelecido desde as primeiras gravações do samba brasileiro, sendo a mais conhecida a gravação de Pelo telefone por Donga, qual seja o projeto de construir um gênero musical que realizasse a concatenação máxima de letra/melodia/harmonia/ritmo/ canto. Trata-se, na verdade, de uma releitura desse projeto que está na raiz da invenção da canção brasileira.

A Bossa Nova, num cenário de transbordamento de um ou de outro desses elementos, propõe um recorte dos excessos numa média perfeita. Para dar um exemplo, veja-se o aspecto canto: o canto de João Gilberto (não só dele, mas de todos os outros - Tom Jobim, Carlinhos Lyra, Nara Leão, Edu Lobo, etc.) não é contido por mera limitação vocal. 0 canto moderado, "baixinho", propõe, na realidade, explorar uma média em que a voz nem se estabelece nas alturas do "bel canto" (também chamado de "dó de peito"), nem no extremo em que o canto deixa de ser canto e passa a ser fala, sussurro.

Ao mesmo tempo, o acompanhamento instrumental busca adequar-se a essa proposta de dicção oral. Como acompanhar um canto prosaico com uma grande orquestra de cordas ou de percussão? Para esse intento, basta o violão, instrumento ícone da tradição musical brasileira, embora não importe a quantidade de instrumentos: até uma orquestra é admitida desde que se comporte como um instrumento. No caso do violão, este não poderia ser tocado de qualquer maneira. Em consonância com o canto médio dos cantores bossanovistas, propõe-se o violão tocado com os arpejos da mão direita "para dentro", de modo fechado, com os dedos formando uma concha, de modo a produzir uma sonoridade contida.

E os espaços para a execução dessa música? Embora a tecnologia da época já permitisse a amplificação do som, uma música baixa, com acompanhamento camerístico, pedia lugares fechados, pequenos. Bares, boates, pequenas casas de show (CAMPOS, 1993). Nas gravações em estúdio, a tecnologia foi usada não para projetar ou amplificar a voz, mas para reduzir a posição da orquestra, que passa a funcionar como se fosse um único instrumento, sem nenhuma primazia em relação aos instrumentos individuais, como o violão, o piano e a bateria.

Por outro lado, as letras tematizam a leveza, o sentimento moderado. Nem o eufórico, nem o trágico. Nem a alegria empolgante, nem a tristeza amargurada. 0 bossanovista está de bem com a vida, mesmo com os seus reveses. 0 abandono da mulher amada não é visto como o "fim do mundo". A sorte na conjunção amorosa não lhe causa frenesi eufórico. Para dar um pequeno exemplo, tomemos a canção Tereza da praia, de Tom Jobim e Billy Blanco, em que dois homens se descobrem, através de um diálogo, namorando a mesma mulher que conheceram na praia. 0 que em canções anteriores seria retratado como uma tragédia (um dos homens matando o outro, maldizendo a mulher ou chorando sua derrota) termina nesta canção em fraterno acordo, no qual os dois abrem mão da esperta garota, que não é julgada e sim deixada "aos beijos do sol e abraços do mar" em proveito da manutenção da amizade entre os dois rapazes.

\section{2 - A música cearense: relendo e rasurando a tradição}

É indiscutível que, depois da Bossa Nova, a música brasileira jamais foi a mesma, mas é preciso dizer que nem todos aderiram incondicionalmente ao movimento. Notese que a Bossa Nova não se resume a um gênero, mas consiste em toda uma forma de conceber e fazer canção e até mesmo outras manifestações artísticas ${ }^{1}$. SANCHES (2000) chega a considerar que o espírito que marcou a Bossa Nova foi o mesmo que influenciou o cinema, a arquitetura e o teatro do fim dos anos 1950 e início dos anos 1960. No entanto, a irrequieta heterogeneidade da música brasileira, mesmo sob intensa pressão do mercado e da mídia, prosseguiu na exploração dos veios arquetípicos abertos desde a fundação do país, ora misturando-os, ora cultivando sua "pureza" respectiva.

Diferentemente do que disse Caetano Veloso em relação a uma possivel linha evolutiva da Música Popular Brasileira, capitaneada pela Bossa Nova e à qual o Tropicalismo teria vindo dar continuidade, há que considerar, portanto, que existem diversas linhas evolutivas na MPB, porque esses veios não pararam no tempo nem foram substituídos: também evoluíram. A música cearense que mais pôde se expressar na mídia, por exemplo, se posicionou em linha com outras vertentes da Música Popular Brasileira, mas, também como os bossanovistas, relendo a tradição, embora não com os mesmos propósitos. Uma delas é a referenciada na cultura e na realidade do Nordeste setentrional (principalmente Ceará, Maranhão, Pernambuco e Paraíba).

Os compositores e cantores cearenses mais expressivos (Belchior, Ednardo e Fagner), sem esquecer de Amelinha, Cirino, Fausto Nilo, Rodger Rogério, Téti, dentre muitos outros, exploraram tal linha que, se nutrindo, assim como os inventores do samba, de ritmos e musicalidades egressas dos folguedos e danças populares formadas pela conjunção das tradições europeias (gêneros como a modinha e o schottisch, o trovadorismo, as danças coletivas e circulares - quadrilha, fandango, etc.) com os ritmos e danças sincopados de origem afro-brasileira e indígena, constitui um dos arquétipos musicais do que hoje se chama MPB (MIRANDA, 2007).

Está certo Gilberto Gil (em CAMPOS, 1993) quando afirma que Luís Gonzaga é o grande agente mediador 
dessas tradições, mas ele erra quando o compara a João Gilberto. Na verdade, Luís Gonzaga parece ser o Donga dos ritmos nordestinos. É ele que, visionariamente, como Donga e outros, transforma a música desse caldeirão buliçoso de manifestações populares, desembaladas (sem embalagens), consumidas e praticadas (sem distinção clara entre esses dois gestos) pelo povo nordestino, principalmente das regiões interioranas do Nordeste (não necessariamente rurais, mas também praieiras) em um produto condizente com o gosto das massas dos grandes centros urbanos e o traz para o mercado nacional provocando, se não um impacto, mas uma repercussão talvez tão forte quanto o da Bossa Nova (e só nesse sentido ele pode ser comparado a João Gilberto).

Se hoje não é possível falar de Música Popular Brasileira sem falar no samba, também não é possível falar dela sem falar dessa vertente nordestina setentrional. A música cearense moderna (da década de 60 em diante) vai beber nesse veio, só que não apenas nele, e aí talvez tenha havido não apenas uma releitura, mas também uma rasura. Marcada pela urbanização desnorteante a que boa parte do povo nordestino por necessidade teve que se submeter, e com ele seus artistas, a música desses cearenses vai sofrer grande influência da música anglo-americana "jovem" da época, que já exercia fascinação sobre a juventude do período por seu caráter de rebeldia e de inconformismo (cf. a Jovem Guarda e o Tropicalismo), embora de forma um tanto reticente (compreensível em tempos de ditadura de direita e de patrulha ideológica de esquerda) (COSTA, 2012).

Especificamente em relação à voz cantada, o "Pessoal do Ceará", além de incorporar elementos da tradição nordestina (como os aboios, os cantos de trabalho, os cânticos das carpideiras e romeiros, etc) ${ }^{2}$, também absorve o timbre característico do gênero conhecido nos países anglo-saxões como "cock" rock ${ }^{3}$. Segundo NEDER ${ }^{4}$, a voz nesse estilo "consiste em um som áspero, que é produzido essencialmente pela garganta e pela boca, com uma utilização mínima das câmaras de ressonância do peito e da cabeça, e através de uma forte tensão das cordas vocais". Não se tratou, como se pode perceber, de uma incorporação tropicalista de influências contrastantes, das quais teria sido necessário aparar muitas arestas.

Evidencia isso o fato de Belchior ser recorrentemente citado ${ }^{5}$ como um compositor bastante influenciado por Bob Dylan, pelas músicas simples, letras longas e pela voz áspera, além de citar o compositor americano em algumas de suas composições, mais explicitamente em Lira dos vinte anos ${ }^{6}$ (BELCHIOR, 1988). Já Fagner, gravou, em 1987, o LP Romance no deserto, título homônimo ao da versão (feita por Fausto Nilo) da canção de Romance in Durango, de Bob Dylan.

Então, podemos dizer que a música cearense não só não adere à vaga da Bossa Nova, como se posiciona contra a estética bossanovista não só porque a Bossa Nova exclui, em seu recorte de excessos, a vertente nordestina (isso vai tentar ser redimido pelos que, no interior do movimento, fizeram a dissidência intitulada "Canção de protesto"). A própria forma de cantar dos cearenses comete "pecados" condenados pela estética bossanovista. Ouça-se, por exemplo, o "trinado" ou vibrato das interpretações de Ednardo e Fagner (acompanhando neste uma vibração vertical da cabeça); a voz metálica e um tanto estridente deles dois e também de Rodger Rogério, Fausto Nilo, Téti e Amelinha (comparem-se as vozes de ambas com as vozes apolíneas de Nara Leão ou Sylvinha Teles); os sussurros sensuais e a rouquidão, bem como os trechos em murmúrios rápidos, da interpretação de Belchior. Em todos esses casos se ultrapassam os limites da contenção praticada pelos bossanovistas. A rascante melancolia de canções como Retrato marrom (Rodger Rogério e Fausto Nilo), Asa partida (Fagner e Abel Silva) e Beleza (Fagner e Brandão), cantadas por Fagner; os protestos e as ironias ferinas de Belchior e Ednardo, tudo isso é impensável ou soaria muito estranho nas vozes de João Gilberto ou Roberto Menescal.

\section{1 - 0 berro de Ednardo}

No entanto, pensamos que a Bossa Nova deixou, além dos muitos legados, uma espécie de legado colateral e, nesse ponto, os cearenses foram beneficiados pelo movimento: depois de João Gilberto, o ouvido musical brasileiro, já bastante sensivel, se abriu para outras texturas vocais que não tinham lugar anteriormente, o que provocou um profundo enriquecimento da paleta de vozes masculinas e femininas, que puderam sair dos banheiros ou das esquinas diretamente para o estúdio ou para o palco. Isso encorajou as gerações de cantores a exporem suas vozes no mercado de tal modo que podemos afirmar sem medo que sem João Gilberto não haveria nem Fagner, nem Belchior, nem Ednardo, nem qualquer um dos outros citados aqui enquanto personae cantantes.

Podemos analisar todo esse movimento de troca entre a Bossa Nova e a música cearense em duas canções dele resultantes: Berro (Ex.1) e Abertura (EDNARDO, 1976).

1. Os novos, os novos

2. Corações aos pulos

3. As novas, as novas

4. Transações e sustos

5. As velhas câmeras não fotografam minha emoção

6. As velhas câmeras não fotografam minha emoção

7. Sentados num banquinho alto

8. Microfone e violão

9. Quilografados comportadamente, somos umas vacas

10. Retalhados neste açougue, atenção!

11. Os novos, os novos

12. Patins, coxão e filé

13. As velhas coisas

14. Pelancas, ossos, quem quer?

15. Do boi só se perde o berro

16. Só se perde o berro

17. E é justamente o que eu vim apresentar

18. Justamente o que eu vim apresentar.

Ex.1 - Letra da canção Berro, de Ednardo. 
Nosso objetivo aqui é mostrar que essa divergência é mais do que de "estilo" ou de "influência". Ela é mesmo de proposta estético-ideólogica, manifestada nos meandros sutis das letras das canções dos compositores retromencionados.

Em Berro, o título da canção já remete a uma forma de cantar que destoa da proposta bossanovista. Se considerarmos que a canção é um gênero cujo modo de enunciação característico é o canto e, no caso dos bossanovistas, um canto moderado, contido, podemos então pensar em uma oposição entre "canto" e "berro", ou seja, que, se as canções bossanovistas são feitas para ser cantadas, a de Ednardo deve ser "berrada", isto é, enunciada/ouvida como um grito animal ou humano insistente e repetido: pretende-se, ela mesma, um berro. 0 gesto enunciativo do título, portanto, aparenta um desinvestimento ou um reinvestimento genérico como forma de travar uma polêmica com aquele que é considerado o gênero que atingiu a mais perfeita conciliação entre todos os aspectos do dispositivo cancional, neutralizando inclusive a contradição entre os elementos da tradição (o samba) e da modernidade (o jazz) que lhe são constituintes (GARCIA, 1999). Mas essa polêmica com a Bossa Nova em relação à forma de conceber o canto popular aparece não apenas no título da canção.

No início da canção encontra-se certamente uma referência ao espanto provocado pelo advento da Bossa Nova, porém em tom de constatação de que "novos espantos" ("corações aos pulos", "transações e sustos") tomaram o lugar daqueles causados pelo movimento, tornado consequentemente velho. Essa "velhice" é um ponto de vista também assumido pelo enunciador, que, numa muito provável referência intertextual à "Rolley Flex" da canção bossanovista Desafinado, declara que "as velhas câmeras não fotografam" sua emoção.

No $7^{\circ}, 8^{\circ}$ e na primeira parte do $9^{\circ}$ verso, a canção se refere criticamente à performance típica dos cantores de Bossa Nova ("Sentados num banquinho alto / Microfone e violão") e à atitude e ao lugar que the cabe no mercado fonográfico ("Quilografados comportadamente"). Logo no final desse mesmo verso, a metáfora "somos umas vacas" dá continuidade a essa crítica pois o termo "vacas" significa, no falar provinciano, "indivíduos faltos de energia, frouxos, moleirões, covardes"8.

No verso seguinte, também o espaço da enunciação é metaforizado (dêixis metafórica): "neste açougue", ajudando a completar a cenografia metafórica do açougue, que irá prosseguir até quase o final da canção. Nessa cena, com certeza depreciativa, associam-se os termos da dicotomia estabelecida no inicio (novos velhas) com algumas partes da vaca referidas através do discurso (léxico e pregão) especializado no recorte e no comércio da carne: "Os novos, os novos / Patinho, coxão e filé / As velhas coisas / Pelancas, ossos, quem quer?". A evocação dessa última prática possibilita, assim, 0 acréscimo de mais um matiz de significado para o termo "vacas", qual seja o de <corte bovino> e, por sua vez, para qualificar os cancionistas que, "retalhados" (patinho, coxão, filé, pelancas, ossos), podem ser vendidos como produtos em um "açougue" (mercado fonográfico).

É necessário dizer que tal captação interdiscursiva gera uma aproximação entre o funcionamento do "mercado fonográfico" e o do "mercado de carnes". Essa comparação sugere que o tratamento que é dado pelo mercado fonográfico aos artistas é assimilado àquele que "as vacas" recebem em um açougue, ou seja, ambos são dissecados e, embora aparentemente exaltados, perdem sua personalidade. As vacas não são mais vacas, são carne, produto de compra e venda, não possuem sequer sua animalidade, assim como os cancionistas, que não são mais artistas na medida em que têm que abdicar de parte da originalidade e identidade de sua arte e cultura em favor das expectativas do gosto do público que lhes paga os serviços.

É notório que esses mecanismos de interdiscursividade implicam, assim, não só em diálogos entre dois ou mais enunciadores, mas no confronto entre diferentes esferas sociais, como a do "mercado" de carnes e a do "mercado" fonográfico. Desse modo, podemos "ouvir", ao mesmo tempo, nessa encruzilhada de vozes, o açougueiro que oferece os cortes bovinos "novos" (patins, coxão e filé) e "velhos" (pelancas, ossos) e a voz do mercado fonográfico que está sempre investindo em "novos" artistas ("patins, coxão e filé") e repetindo os "velhos" ("pelancas, ossos, quem quer?") pelo lançamento de coletâneas e na pressão contra a inovação. 0 enunciador polemiza, assim, com o mercado fonográfico e com quaisquer coenunciadores, como os bossanovistas, que sejam coniventes com a forma de funcionamento dessa prática social. 0 próprio ato de polemizar já é em si mesmo antibossanovista, pois, como indica GARCIA (1999), é marca distintiva da Bossa Nova justamente a neutralização do conflito e contradição que lhe são inerentes ${ }^{9}$.

Cabe observar que o verso "Do boi só se perde o berro" é um recurso polifônico que, enquanto enunciação de um provérbio, consiste em lançar mão de uma voz de autoridade incontestável, representante da opinião pública, de um saber imemorial (MAINGUENEAU, 2010), com o propósito de captar tal legitimação. 0 uso dessa voz, ao mesmo tempo, dá continuidade e reforça a metáfora /cantorescompositores de MPB/ = /vacas-bois/, desqualificativa da categoria, na qual o enunciador admite se inserir. Por outro lado, ele se aproveita do elemento "berro", para se demarcar de seus adversários bossanovistas e desqualificar o mercado fonográfico e quaisquer outros que sejam coniventes com as regras da indústria cultural. 0 provérbio serve ainda como "deixa" para o verso final ("E é justamente o que eu vim apresentar"), que traduz uma afirmação sobre o próprio fazer discursivo (metadiscurso) aparentemente se autodesqualificando, mas que reflete um propósito de circunscrevê-lo a uma determinada região do discurso, separando seu dizer dos outros dizeres que com ele coexistem e com os quais polemiza, como o dos outros compositores (classificados como "vacas"), o do mercado fonográfico (que animaliza os cancionistas, 
comparado a um açougue), o da pecuária (que percebe apenas o valor monetário do boi) etc. Concluímos, então, que a imagem do enunciador corresponde a alguém que protesta (metaforizado como um boi que berra) contra a massificação do mercado fonográfico, diferenciando-se, assim, da imagem construída para seus coenunciadores, os bossanovistas ("vacas"), que se acomodam, "quilografados comportadamente", diante das condições que lhe são impostas.

Se considerarmos que, em Análise do Discurso, o interesse não se volta para os sujeitos considerados independentemente das situações de enunciação, podemos observar ainda, tendo em vista a época na qual a canção foi lançada, 1976, uma coincidência entre o enunciador linguístico, artista questionador/polêmico, e o sujeito do enunciado, um compositor/cantor que produz e canta a canção (papel ligado ao gênero do discurso), instituindo um compromisso com a criatividade da sua produção e a ruptura com a massificação do mercado $^{10}$. Isso se evidencia dois anos depois quando o compositor rompeu com a gravadora RCA e lançou o LP Cauim (1978), gravado pela WEA em 1978, que "acentua o ritmo dos maracatus, as influências indígenas, como também atualiza e recria a memória coletiva ao reportar-se à Confederação do Equador e à Revolução de 1817, movimentos significativos da história cearense" (PIMENTEL, 1994, p.114). A oposição às condições impostas pela indústria fonográfica e a luta pela valorização da criatividade do artista, práticas e temas presentes na carreira de Ednardo, parecem construir um certo elemento identitário entre integrantes do "Pessoal do Ceará", na medida em que Belchior também revela essa mesma "preocupação poética", nos seus elepês Todos os sentidos, lançado em 1978, e Objeto Direto, em 1979 (PIMENTEL, 1994)"11, e que é conhecida a atuação de Fagner junto à gravadora CBS em prol de diversos artistas nordestinos durante as décadas de 1970 e $1980^{12}$.

\section{2 - Um novo ingrediente na ração}

1. Alguém colocou um novo ingrediente na ração

2. E no pacato terreiro formou-se enorme confusão

3. Eu já desconfio que essa algazarra em alguma vai dar

4. Pois a bicharada toda do terreiro

5. Já tem outra maneira de cantar

6. (Eu vou mandar prender...)

7. Quém, quém, quém, pó dó pó

8. Corocó-có có có co

9. Pó pó pó pó pó

10. 0 pato...

11. Porque todo o pato

12. Tem que cantar alegremente

13. Alegremente cantar o pato e toda a gente

14. Alegremente o pato é

15. Alegremente o pato está

16. No tucupi, no tacacá

17. (Comeram o pato).

Ex.2 - Letra da canção Abertura, de Ednardo.
No mesmo LP, quatro canções depois, está o sambachoro Abertura (Ednardo). Cabe observar, de início, que o título é homônimo ao do festival de música promovido pela Rede Globo de Televisão, em 1975, do qual Ednardo foi finalista com a canção Vaila (Ednardo / Brandão) gravada nesse mesmo LP. A presença dessas duas canções nesse disco de 1976, juntamente com Classificaram (Ednardo / Brandão) ${ }^{13}$, parece mostrar que a experiência da participação no festival da Globo provocou reflexões e desejo de repercuti-las através de canções. Mas se a "abertura" do título do festival talvez se referisse obliquamente à distensão política anunciada pelo governo do Presidente Geisel a partir de 1974, a "abertura" da canção de Ednardo certamente nos fala da abertura promovida e também sofrida pelo movimento Bossa Nova no âmbito da Música Popular Brasileira.

Sua cenografia narra um acontecimento localizado no passado ("Alguém colocou um novo ingrediente na ração") e suas consequências ("E no pacato terreiro formou-se enorme confusão"), para, logo no verso 3, indicar a avaliação do enunciador ("Eu já desconfio que essa algazarra...") em relação ao acontecimento e frente a algo que se realizará em um futuro próximo ("em alguma vai dar"). Nos dois outros versos da estrofe, esse enunciador reforça a sua desconfiança/ previsão com uma explicação ("Pois a bicharada toda do terreiro"), mais que isso, uma constatação: "Já tem outra maneira de cantar".

Até esse momento, a letra da canção assume uma cenografia que a associa a uma fábula ou a uma história infantil, em nada deixando ver seu caráter metadiscursivo (referência ao próprio discurso do qual ela emana, isto é, o discurso literomusical). Mas na segunda estrofe, é evidente a intertextualidade com a canção 0 pato (Jayme Silva / Neuza Teixeira) ${ }^{14}$, a qual dá indícios de que essa nova maneira de cantar ("novo ingrediente da ração") é uma referência à Bossa Nova, ou mais precisamente a João Gilberto, que gravou a composição em seu LP 0 amor, o sorriso e a flor, de 1960, a sua maneira contida de cantar, saindo radicalmente da tradição dos grandes cantores do rádio, famosos por seus "vozeirões", e a sua forma de tocar violão, adotando uma batida diferente que desloca o acento da tradicional batida de samba. Mais uma vez Ednardo recorre a metáforas alegóricas ${ }^{15}$ para referir-se à cena literomusical.

Há pelo menos duas leituras possíveis para essa cenografia alegórica:

a) "Alguém" seria João Gilberto; o "novo ingrediente", a batida de violão diferente do cantor ou talvez o elemento jazzístico (esses elementos não são explicitados na canção); o "pacato terreiro" seria o campo discursivo literomusical brasileiro pré-bossanovista; e a "enorme confusão" seria o impacto dessa invenção que fez com que jovens insatisfeitos e cansados do cenário musical da 
época passassem a adotá-la ("Pois a bicharada toda do terreiro / Já tem outra maneira de cantar").

b) "Alguém" seria o mercado fonográfico; o "pacato terreiro" seria o campo discursivo literomusical brasileiro da época (primeira metade da década de 1970); o "novo ingrediente", os ruídos das novas tendências da música mundial, talvez a música pop ou o rock, ou, quem sabe, a própria mercantilização da música; o "pacato terreiro" seria o campo discursivo literomusical brasileiro bossanovista que continuava ignorando uma realidade já em franca transformação; e a "enorme confusão" seria a perplexidade diante da grande adesão da juventude aos ritmos vindos de fora ("Pois a bicharada toda do terreiro / Já tem outra maneira de cantar").

Independente da interpretação, o fato narrado e a suas consequências, constatadas pelo enunciador, constroem uma espécie de cenário para a entrada do pato, que faz parte dessa "bicharada", ou seja, da comunidade discursiva literomusical brasileira. Essa relação alegórica se confirma não só por meio da captação das interjeições "Qüem, qüem, qüem", que imitam seu cantar e estabelecem uma intertextualidade com a famosa interpretação joãogilbertiana, mas também pela alusão ao estilo de cantar do intérprete bossanovista e ao próprio gênero musical no qual a canção é executada.

A intertextualidade com a canção mencionada continua e se explicita no oitavo verso de Abertura pela citação textual e melódica do seguinte segmento da canção de Neuza Teixeira e Jayme Silva (Ex.3).

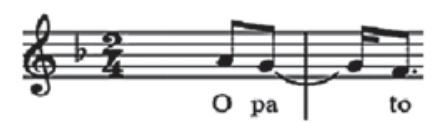

Ex.3 - Fragmento da partitura da canção 0 pato, de Neuza Teixeira e Jayme Silva - dois primeiros compassos.

Isto mostra, então, que a cenografia alegórica de Abertura é de "segunda mão", isto é, trata-se da mesma usada na canção gravada por João Gilberto, como se fosse sua releitura ou continuação.

0 pato, por sinal, que é uma canção dos anos 40 do repertório do grupo Garotos da Lua, mas nunca gravada por eles (SEVERIANO; MELLO, 1998), também tem um cunho metadiscursivo, pois se trata de uma alegoria bem humorada do mundo literomusical da época, fazendo inclusive referência ao samba e especificamente ao choro Tico-tico no fubá (ZEQUINHA DE ABREU, 1931). Trata-se provavelmente de uma sátira das más vozes e dos maus cantores de então que não seriam capazes de reconhecer uns nos outros suas respectivas más qualidades. Podemos dizer que a gravação de João Gilberto ressignifica esta canção possibilitando a leitura de uma atitude carnavalesca, no sentido que Mikhail Bakhtin atribui a este adjetivo. Em seu livro "A cultura popular na Idade Média e no Renascimento", Bakhtin (2002) nos fala dos elementos que compõem o carnaval. 0 carnaval, segundo o autor, é desde a Idade Média, quando nasceu, um momento em que se instauram em profusão lúdica imagens corporais, simbólicas, etc., que subvertem a corporalidade e a semiótica bem comportada e hierarquizada do status quo: comer e ser comido, o corpo grotesco, o baixo ventre, as máscaras, a metamorfose. No plano discursivo, a ironia, a sátira, a paródia, as estruturas e causalidades invertidas. Em Bakhtin, carnavalização não se refere apenas ao carnaval, de modo que, abstraindo da cena medieval e renascentista, a carnavalização remete a toda uma concepção de mundo risonha e subversiva dos valores oficiais.

No entanto, Bakhtin ressalva que nem todo riso é carnavalesco. 0 autor russo nos fala em diferentes formas do risível e destaca que, na forma do riso carnavalesco, os próprios enunciadores são objeto do escárnio. A nosso ver, é bem o caso de 0 pato, ao menos na leitura joãogilbertiana. Nela se estabelece uma espécie de identificação entre o modo de cantar do pato e a voz de João Gilberto; entre o inusitado acontecimento de um pato resolver cantar ("A voz do pato / Era mesmo um desacato") e a estética bossanovista. Tem-se, portanto, um discurso ambivalente, em que o sujeito se autorrebaixa (comparando sua própria voz ao grasnar de um pato) e ao mesmo tempo se autolegitima não apenas através do tom irreverente e desabusado dos personagens da cenografia, mas do próprio fato de ser aquela "voz de pato", em perfeita afinação, a que está propiciando ao ouvinte ouvir a narrativa da canção.

É possivel ler a última estrofe ("Porque todo o pato / Tem que cantar alegremente / Alegremente cantar o pato e toda a gente / Alegremente o pato é / Alegremente o pato está") como uma ironia. Sendo assim, tomando o pressuposto de que "o pato e toda gente" estão cantando alegremente, duas vozes soam em tensão. A primeira é assertiva e poderia ser parafraseada da seguinte forma:

a) Os patos e toda gente devem cantar alegremente, é o seu dever; eles devem cantar alegremente porque alegre é seu estado de espírito e têm motivos para isso.

A segunda é polêmica e pode ser expressa do seguinte modo:

b) Os patos e toda gente não deveriam cantar alegremente; não há motivos para essa alegria nos dias de hoje.

Como se sabe, a estratégia irônica consiste em dizer algo através de proposição que diz o contrário do ponto de vista pretendido e que se põe como absurda. Para DUCROT (1987), ela encena duas figuras enunciativas: uma responsável pelas palavras enunciadas, mas não pelo ponto de vista que elas expressam, e a outra por esse ponto de vista. Um locutor enuncia palavras que manifestam um ponto de vista em total oposição ao seu e que, portanto, deve ser atribuído à voz de outra figura discursiva que ele denomina enunciador. Assim a primeira interpretação (a) 
do trecho da canção mencionado acima está ligada ao efetivamente dito, à voz do locutor; sendo que, na verdade, $o$ enunciador assume o ponto de vista expresso em $b$.

Mas o importante é perceber que o sujeito irônico pressupõe que, mais eficaz do que a apresentação direta de seu ponto de vista para a legitimação de seu posicionamento, é a sua manifestação indireta e derrisória. No caso da canção aqui analisada, a ironia em questão se alia à alegoria subversiva do pato e ganha contornos de violência simbólica e carnavalesca (sempre no sentido bakhtiniano). 0 alvo desse etos carnavalesco são dois possíveis "regimes" indicados pelo verbo "tem (que)":

a) Ao regime autoritário da época, que procurava a todo custo criar uma imagem otimista e triunfalista do país.

b) Ao "regime ético" da Bossa Nova (adotado também pelo Tropicalismo) que promovia uma "reabilitação (...) da linguagem e da alegria da composição (...) que no periodo anterior estava reservada apenas para as músicas primitivas e carnavalescas" (SANT'ANNA, 1986, p. 217).

Essa violência zombeteira é coroada pelos versos finais: "14. Alegremente o pato é / 15. Alegremente o pato está / 16. No tucupi, no tacacá / 17. (Comeram o pato)". 0 advérbio "alegremente", que aparece em todos os versos da última estrofe, "pula" de verso em verso mudando de função sintática e de importância. Ele começa adjunto adverbial do verbo cantar (portanto, em posição secundária) (verso 12); no verso seguinte continua na mesma função mas passa a ser topicalizado, isto é, fica em primeiro plano; no verso 14 , ele aparece, de modo inusitado, gramaticalmente estranho, como predicativo do sujeito "pato" e ainda topicalizado, estabelecendose então como característica inerente ao pato. 0 verso 15 se distingue do terceiro apenas pela substituição do verbo "é" pelo verbo "está". Este verbo aparentemente diminuiria a importância temática de "alegremente", na medida em que deixaria de caracterizar uma inerência do pato para indicar apenas um estado. Porém, o verso seguinte ("16. No tucupi, no tacacá") transitiviza o verbo estar e dá à substituição o papel de conduzir o ouvinte ao grotesco, já que tucupi e tacacá são pratos feitos com pato, obviamente, morto.
A letra é concluída didaticamente com a expressão "comeram o pato" cantada como os "breques" dos famosos sambas de breque da década de 50. Esse final apresenta pelo menos duas possibilidades de leitura:

a) 0 "pato", em virtude de sua alienação, foi "devorado", isto é, absorvido pela indústria do entretenimento, que teria todo interesse em que ele cantasse "alegremente".

b) 0 "pato" foi "comido" no sentido antropofágico, já que foi incorporado à cultura popular, simbolizada pelos pratos da culinária popular paraense.

Seja como for, a ideia da morte do pato alegre, representante alegórico da Bossa Nova e de seu cantor maior e líder João Gilberto, aponta para um posicionamento divergente que rompe com uma estética da leveza, da distensão e da contemplação que parece ser o fulcro principal da proposta bossanovista. Essa crítica pode ser ainda mais abrangente e atingir o Tropicalismo, na medida em que tem também como alvo o princípio da "alegria"16, encarada pelo movimento como energia subversiva e regeneradora seja contra a melancolia dos nostálgicos, a sisudez dos esquerdistas da época ou a truculência da direita que estava no poder.

\section{3 - Considerações finais}

Apresentamos e trabalhamos neste artigo a hipótese de que o que se evidencia nas vozes, nos gêneros e nos arranjos das canções daqueles que, nos anos 70, foram denominados "Pessoal do Ceará" também se apresenta nos textos literomusicais, ainda que de modo esporádico. Ou seja, se no plano da expressão musical (melodia, arranjos, investimento vocal, etc.) um Fagner, um Belchior, um Ednardo, ou mesmo uma Amelinha ou uma Téti, se mostram francamente antibossanovistas pelo que apresentam de passionalidade e de expansividade, com suas vozes "acres", temáticas rascantes e ironias ferinas, em alguns momentos metadiscursivos é possível localizar um discurso que polemiza com a proposta estético-ideológica da Bossa Nova. 0 mais importante é mostrar que essa crítica é em si mesma um gesto antibossanovista, dado que sua intensidade e violência não se coadunam com a regra de contenção dessa estética. Outros trabalhos poderão certamente localizar e analisar no trabalho do grupo outros momentos similares ao que trabalhamos aqui em Berro e Abertura, confirmando e reforçando nossa hipótese. 


\section{Referências}

BAKHTIN, Mikhail. A Cultura Popular na Idade Média e no Renascimento: o contexto de François Rabelais. São Paulo: Hucitec, 2002.

CAMPOS, Augusto de. Balanço da Bossa e outras bossas. São Paulo: Perspectiva, 5a ed., 1993.

COSTA, Nelson B. da. Música popular, linguagem e sociedade: analisando o literomusical brasileiro. Curitiba: Editora Appris, 2012.

(org.). O charme dessa nação: música popular, discurso e sociedade brasileira. Fortaleza: Expressão Gráfica e Editora, 2007.

DUCROT, Oswald. O Dizer e o dito. Campinas: São Paulo, Pontes, 1987.

GARCIA, Walter. Bim bom - A contradição sem conflitos de João Gilberto. São Paulo: Paz e Terra, 1998.

GAVA, José Estevam. Momento Bossa Nova. São Paulo: Annablume / Fapesp, 2006.

MAINGUENEAU, Dominique. Doze conceitos em análise do discurso. São Paulo: Parábola, 2010.

MELLO, Zuza Homem de. João Gilberto. Publifolha: São Paulo, 2001.

MIRANDA, Dilmar Santos de. "Música Popular e Sociedade Brasileira". In COSTA, Nelson Barros da. (org.). 0 charme dessa nação: música popular, discurso e sociedade brasileira. Fortaleza: Expressão Gráfica e Editora, 2007.

PIMENTEL, Mary. Terral dos Sonhos: o cearense na música popular brasileira. Fortaleza: Secretaria da Cultura e Desporto do Estado do Ceará / Multigraf Editora, 1994.

SANCHES, Pedro Alexandre. Tropicalismo - decadência bonita do samba. São Paulo: Boitempo, 2000.

SANT'ANNA, Alfonso Romano de. Música Popular e Moderna Poesia Brasileira. 3. ed., Petrópolis: Vozes, 1986.

SEVERIANO, Jairo; MELLO, Zuza Homem de. A canção no tempo. Vol. 2. São Paulo: Ed. 34, 1998.

\section{Referência discográfica}

EDNARDO, J. S.C.S. (VIK) RCA Victor, 1976.

\section{Referências eletrônicas}

FAOUR, Rodrigo. "Ednardo está de volta com cinco discos de uma vez só". Click Music. Jan. 2001. Seção matérias jornalísticas. Disponível em: http://www.ednardo.com.br. Acesso em : 04 dez 06.

FERREIRA, Aurélio B. de H. Dicionário Aurélio Eletrônico. São Paulo: Nova Fronteira, 1994.

MILLARCH, A. "Belchior, uma obra com personalidade". Caderno Almanaque. Música. Paraná: 1991. p. 4. Disponível em: http://www.millarch.org/artigo/belchior-uma-obra-com-personalidade. Acesso em: 13 abr 2010.

"Fagner, a trajetória de um trabalhador musical". Caderno Almanaque. Música. Paraná: 1991. p. 7. Disponível em: http://www.millarch.org/artigo/fagner-trajetoria-de-um-trabalhador-musical. Acesso em: 11 ago 2012.

MOURA, D. Dylan "Apenas um rapaz americano". Jornal Diário do Nordeste, Fortaleza, 12 jun. 2005, Caderno 3, Fortaleza, 12 jun 2005. Disponível em: http://diariodonordeste.globo.com/materia.asp?codigo=255265. Acesso em: 02 abr 2010

NEDER, A. "Um homem pra chamar de seu: teoria literária, música e transformação social". GT: Elas na pauta: mulheres e canções. PUC-Rio (Disponivel em: http://www.fazendogenero7.ufsc.br/artigos/A/Alvaro_Neder_03.pdf. Acesso em: 26. Mai 2010.

SHUKER, R. Vocabulário de música pop. Tradução Carlos Szlak. - 1. ed. - São Paulo: Hedra, 1999. (Disponível em: http:// www.4shared.com/get/38271182/8cdb509c/Vocabulrio_de_Msica_Pop.html) Acesso em: 26 mai 2010.

\section{Notas}

1 cf. GAVA (2006).

2 Evidentemente, sofre também, como praticamente todos os compositores de sua época, influência da música popular que era veiculada pela mídia da época, principalmente a radiofônica, ou seja, sambas, marchinhas, valsas, choros, baiões, etc.

3 De acordo com SHUKER (1999), o termo "cock rock" surgiu como alternativa a hard rock, enfatizando a sensualidade masculina, muitas vezes explícita e agressiva, suas letras às vezes misóginas e seu imaginário fálico. Os artistas do cock rock são considerados agressivos, dominadores e arrogantes, uma postura evidenciada em suas apresentações ao vivo. (Disponivel em: htp://www.4shared.com/get/38271182/8cdb509c/Vocabulrio_ de_Msica_Pop.html. Acesso em 26 Mai 2010.

4 NEDER, A. "Um homem pra chamar de seu: teoria literária, música e transformação social". Na pauta: mulheres e canções. PUC-Rio. Disponivel em http://www.fazendogenero7.ufsc.br/artigos/A/Alvaro_Neder_03.pdf. Acesso em: mai 2010. 
5 MOURA, D. "Dylan: 'Apenas um rapaz americano"'. Jornal Diário do Nordeste, Fortaleza, 12 jun. 2005, Caderno 3, Fortaleza, 12 jun 2005. Disponivel em: http://diariodonordeste.globo.com/materia.asp?codigo=255265; MILLARCH, A. "Belchior, uma obra com personalidade". Caderno Almanaque. Música. Paraná: 1991. p. 4. Disponivel em:-http://www.millarch.org/artigo/belchior-uma-obra-com-personalidade. Acesso em: mai 2010.

6 "Os filhos de Bob Dylan, clientes da coca cola / Os que fugimos da escola / Voltamos todos pra casa".

7 Isso naturalmente no contexto do cenário musical brasileiro da época, normalmente avesso a influências da música anglo-americana muitas vezes considerada signo da "modernidade", o que é, evidentemente, um equivoco, já que o jazz é tão antigo quanto o samba.

8 Cf. Dicionário Aurélio on line. Disponivel em: http://www.dicionariodoaurelio.com. Acesso em: 20 jan 2010.

9 Sobre como a polêmica é vista na perspectiva da letra bossanovista, recomendamos a audição da canção Discussão, de Tom Jobim.

10 Cabe destacar o comentário de Ednardo, postado na revista eletrônica Click Music, sobre a sua relação inconstante com gravadoras: "Tenho uma mania saudável de não repetir enfoques de trabalho em cada disco. Isso até dificulta meu relacionamento com gravadoras, porque quando uma música sua estoura, elas querem que você faça uma série de outras na mesma linha. Como acredito que os discos ficam mais tempo na Terra do que a gente, acho que é legal ter um cuidado muito grande ao realizá-los. Por isso sempre os fiz com muita dignidade e sempre fui muito criterioso com o que cantar e com o que dizer ao público. Também nunca tive uma preocupação exagerada com o sucesso, embora ele seja sempre bem-vindo, é claro" (FAOUR, 2001).

110 site oficial do cantor, www.brasilianmusic.com.br/belchior, apresenta o ano de 1980 para o lançamento do LP Objeto direto. Acesso em 09 dez 2006.

12 Cf. http://www.millarch.org/artigo/fagner-trajetoria-de-um-trabalhador-musical. Acesso em 11 ago 2012.

13 "Classificaram se classificaram / Se ficaram classe / Classigualaram, classiportaram, classiscutaram / Classi, classi si classificaram / Ficaram sem de sem / De se, de sem / De si, de juventude / E aventura de si, de sem, de se avontadar / Em For qualquer cor po quer lugar / Em For qualquer cor po quer lugar // Pra ver o há inda há ou que é que há de há / Pra ver o há inda há ou que é que há de há / Há de há / Basta o lam pejo inda inquietarde / Ou coragem de se espeda sarar / Basta o lam pejo inda inquietarde / Ou coragem de se espeda sarar / Em qual sonho sacri quersoficio / Em qual sonho sacri quersofício / Basta o lam pejo inda inquietarde / Ou coragem de se espeda sarar".

14 "O pato / Vinha cantando alegremente / Qüem, qüem! / Quando um marreco sorridente / Pediu pra entrar também no samba / No samba, no samba, no samba... // 0 ganso, gostou da dupla / E fez também / Qüem, qüem, qüem! / Olhou pro Cisne / E disse assim: / "Vem! Vem! / Que o quarteto ficará bem"/ Muito bom, muito bem...// Na beira da lagoa / Foram ensaiar / Para começar / 0 Tico-Tico no Fubá... // A voz do pato / Era mesmo um desacato / Jogo de cena com o ganso era mato / Mas eu gostei do final / Quando caíram n'água / E ensaiando o vocal... // Qüem, qüem, qüem, qüem! / Qüem, qüem, qüem, qüem! / Qüem, qüem, qüem! / Qüem, qüem, qüem, qüem, qüem..."

15 E "pecuárias", como diria Chico Buarque (cf. Fazenda modelo - uma novela pecuária, 1975).

16 Os tropicalistas retomam dos modernistas essa ideia, a de que o bom humor e o espírito festivo é uma caracteristica distintiva e traço de resistência do povo brasileiro. A frase "A alegria é a prova dos nove", contida no Manifesto antropófago, de Oswald de Andrade, é citada na canção-manifesto Geleia geral, de Gilberto Gil e Torquato Neto. Cf. ainda Alegria, alegria, de Caetano Veloso, e a "encampação" pelo movimento de figuras como Chacrinha e Jorge Ben.

Nelson Barros da Costa é Mestre em Educação (UFC) e doutor em Linguística Aplicada (PUC/SP - Université de Rouen - FR), com pós-doutorado na Universidade de Paris XII (Val de Marne). É Professor Associado do Departamento de Letras Vernáculas da Universidade Federal do Ceará (UFC). Leciona, pesquisa e orienta dissertações e teses no Programa de PósGraduação em Linguística da UFC na área de Análise do Discurso aplicada ao discurso literomusical brasileiro. Coordena o grupo de pesquisa Discurso, Cotidiano e Práticas Culturais (Grupo Discuta - www.grupodiscuta.ufc.br).

Maria das Dores Nogueira Mendes é Mestre e Doutora em Linguística pela Universidade Federal do Ceará. Pesquisa sobre música popular brasileira, especificamente sobre a música cearense utilizando a Análise do Discurso Francesa, na perspectiva de Dominique Maingueneau, como teoria de base. É professora do Curso de Formação de Docentes em Língua Portuguesa e suas Literaturas da Faculdade Integrada da Grande Fortaleza (FGF). Leciona e orienta monografias na área de Letras, com ênfase em Lingüística e Análise do Discurso. Atua como tutora no Curso de Graduação Semi-Presencial em Letras, organizado pela Universidade Aberta do Brasil, Universidade Federal do Ceará e Instituto UFC Virtual. É membro do grupo de pesquisa Discurso, Cotidiano e Práticas Culturais (Grupo Discuta). 